\title{
Multiplexity in Civilization Studies: Insights from Ibn Khaldun and Said Halim Pasha*
}

\section{Medeniyet Çalışmalarında Çoğulculuk: Ibn Haldun ve Said Halim Paşa'nın Yaklaşımı}

\author{
Mukerrem Miftah \\ Social Sciences University of Ankara, Turkey \\ mukerem.shafi@asbu.edu.tr
}

\begin{abstract}
The study of civilization has always been approached from various perspectives. A closer appraisal of some of these pursuits reveals at least three major trends, especially in the contexts of Islamic and Western civilizations. The first trend employs more of a "historic-empirical" approach; the second emphasizes a "religiophilosophical" approach; and finally, the last trend adopts more of a "multiplex" approach to the study of civilizations. Whilst the first two trends are equally applicable in the study of Islamic and Western civilizations, the "Multiplex" trend is arguably more pronounced in the study of Islamic civilization. The paper argues that "Multiplexity", subsuming multiplicity and complexity both in terms of content and methodological foundations, is best represented by the works of Ibn Khaldun and Said Halim Pasha. This approach to civilization studies, among other things, challenges reductionism both on methodological as well as epistemological grounds. Compared to the other two, it gives due attention to multiple factors, such as economic, political, cultural, religious, historical, philosophical, and physical factors, and the interlocking intricacies among them to account for the phenomenon of civilization. Therefore, it can present us with an alternative and more holistic approach to civilization studies through transcending the impasse posed by historical, economic, physical, racial, religious, and other determinisms and reductionisms.
\end{abstract}

Keywords: Islamic Civilization, Religiophilosophical, Historic-Empirical, Multiplexity, Reductionism

Öz: Medeniyet çalışmasına her zaman çeşitli açılardan yaklaşılmıştır. Bu arayışların bazılarının daha yakından değerlendirilmesi, özellikle Islam ve Batı medeniyetleri bağlamında, en az üç ana eğilimi ortaya koymaktadır. IIlk eğilim daha "tarihsel-ampirik" bir yaklaşım kullanıyor; ikincisi "din felsefesi" yaklaşımını vurgulamaktadır; ve nihayet, sonuncusu medeniyetlerin incelenmesine daha fazla "çoğulculuk" yaklaşımı benimsemiştir. ilk iki eğilim islam ve batı medeniyetlerine eşit olarak uygulanabilse de, "çoğulculuk" eğilimi, İslam medeniyetinin çalışmasında tartışmasız daha

\footnotetext{
"This article is a review of the paper presented at the "4th International Ibn Khaldun Symposium" organized on 19-21 May 2017 in Istanbul.
} 
belirgindir. Çalışma, metodolojik terimlerdeki çoğulculuk ve karmaşıklığı vurgulayan "Çoğulculuk"un en iyi ibn Haldun ve Said Halim Paşa'nın eserleri ile temsil edildiğini savunuyor. Medeniyet araştırmalarına yönelik bu yaklaşım, diğer şeylerin yanı sıra, hem metodolojik hem de epistemolojik gerekçelerle indirgemeciliği zorlamaktadır. Diğer ikisi ile karşılaştırıldığında, uygarlık olgusunu hesaba katma çabası içinde ekonomik, politik, kültürel, dini, tarihsel, felsefi ve fiziksel faktörler ve aralarındaki birbirine geçen karmaşıklık gibi birçok faktöre dikkat çeker. Bu nedenle, medeniyet çalışmalarına alternatif fakat daha bütünsel bir yaklaşım sunabilir ve bu sayede tarihsel, ekonomik, fiziksel, ırksal, dini ve diğer determinizmlerin ve indirgemeciliklerin ortaya çıkardığı çıkmazları aşar.

Anahtar Kelimeler: Islam Medeniyeti, Din Felsefesi, Tarihçi-Ampirik, Çoğulculuk, Indirgemecilik

\section{Introduction}

A systematic study of civilization as a particular field of social science is of a recent phenomenon. Notwithstanding this, social scientists and philosophers have long been writing and theorizing about the nature and future of human civilization. From the fourteenth century North African Ibn Khaldun; the eighteenth century Mireabu and Rousseau; the nineteenth century Guizot, Comte, and E. B. Taylor; the twentieth century Ottoman Islamist thinker and statesman Said Halim Pasha; and to the twenty first century Toynbee, Hodgson, and other Western and non-Western thinkers, were all engaged in the very question of civilization, particularly, its genesis, crisis, decline and revival. Today also, it could be argued that there are many and increasingly sophisticated theoretical formulations engaging civilization and civilizations, past or present. The multiplicity and diversity of perspectives in civilization studies is not only confined to the general idea of "civilization", but also reflected in the discursive formations and proliferation of multiple historical civilizations.

In what follows, I respond to the question of "what are the most common trends and approaches that can relatively capture this multiplicity and diversity? I argue that there are at least three major trends in civilization studies, particularly among theories of Islamic and Western civilizations. Although "historic-empirical" and "religiophilosophical" trends and approaches are abundantly present among these civilizations, the "multiplexity" trend is arguably more pervasive among theories of Islamic civilization. Of the theories of Islamic civilization, I argue that, the works of Ibn Khaldun and Said Halim Pasha present relevant instances. The following paragraphs briefly expand on these core points. In an effort to shed some light upon the overall framework of the present study, and before moving on to the multiplex trend, I will provide a brief overview of the first two trends I have addressed above. 


\section{Emerging Trends in Civilization Studies}

A closer scrutiny of some of the theories of civilization, particularly those of Islamic and Western civilizations, generally unveils at least some three major trends and approaches. Theories explaining Islamic and Western civilizations, due to ontological, epistemological or methodological foundations and tendencies, they either fall into the "historic-empirical" trend, "religiophilosophical" trend, or "multiplexity" trend. The first is more of historically-and-empirically oriented approach to civilization studies; the second draws primarily from philosophy and religious scriptures and sources; and finally, the last one generally involves the mixture of these and other factors and elements and I called this a multiplex trend'. It should be noted, however, that this classification does not pretend to be strictly mutually exclusive nor does it assume exhaustiveness. But, again, this classification can still help us gauge, at least at macro level, the overall trend underlying the theories of civilization. Given space limitation, I will limit my discussion to the theories of Islamic civilization.

\subsection{Historic-empirical Trend}

I define the first trend (also used in a limited, methodological, sense as "approach") as that which principally draws from historically-and-empirically charged approach to the study of civilization². Among other things, studies in this trend emphasis interpreting and explaining issues and factors embedded, for the most part, in particular time and space. Due to this, studies in this trend may argue, for instance, that in the context of Islamic civilization, Islam, starting in the seventh century, gave an ideological impetus or identity to what came to be called Islamic civilization. However, they assign significant roles to what may be called "time and space embedded factors"3. This in some ways reduces Islam into assuming a symbolic role in the making of Islamic civilization.

Islam might have triggered the emergence of a "civilization" through its "ideals" and gave it some "identity". Yet, the civilization implied therein is not necessarily unique to Islam. Rather, it is seen as one having precedence in time and space. In this sense,

\footnotetext{
1 Multiplexity is a commonly recycled concept in sociolinguistics and social network. However, it came to have a different connotation in civilization studies, particularly in the study of Islamic civilization. It was Recep Senturk (Professor and director at the Alliance of Civilizations Institute (ACl), Ibn Khaldun University, Istanbul, Turkey) who reintroduced it with a classic Islamic thought foundations(See, Senturk's book "Open Civilization" (2010)). Multiplexity as used here, however, refers specifically to two key constructs which, I argue, are "complexity" and "multiplicity". Senturk's use, however, is confined to the later conception.

2 It would be worth noting that the historically-and-empirically charged approach or trend does not necessarily function in a philosophical vacuum; rather, a great deal of emphasis is rendered to factors corresponding to a particular time and place.
} 
Islamic civilization is seen as nothing but one part of a greater cultural process subsuming interactions, exchanges, and continuities in a wider context (historical, cultural, and geographical conditions). However, in light of some of its own certain peculiar characteristics which it developed through time, the origin of Islamic civilization is dated back to the seventh century in the Arabian desert, and as such, there was not an Islamic civilization before. However, many theories falling under thereligiophilosophical trend argue that the initial genesis of Islamic civilization was started off with the creation of Adem.

Drawing from my ongoing doctoral research, I argue that Arnold Toynbee $(1972,1952)$ and Marshal Hodgson's (1993, 1974, 1960) theories of Islamic civilization present some important features that generally reflect the historic-empirical trend in the study of Islamic civilization. Among other things, both historians implied or expressively underscored the time and space confinement of Islamic civilization (particularly the seventh century as the point of genesis); both historians took evolution as something axiomatic (in the case of Toynbee, especially in the emergence of the first generation of civilizations); the absence of direct relationship between religion and civilization (particularly between Islam and Islamic civilization) (e.g., Hodgson, Vol. I, 1974; p.71); historicism and cultural relativism (Islam as a cumulative tradition, subjective in different parts of the Muslim world despite the symbolic unity it achieved); both historians believed in multiple civilizations and Islamic civilization as one of them (also both implied one "human" civilization); the Syriac world ("Syriac civilization" for Toynbee and "Irano-Semetic" civilization for Hodgson) was conceived as the religio-cultural springboard for the emergence of Islamic civilization; and Hellenistic tradition as one integral part of Islamic and Western civilizations.

\subsection{The Religiophilosophical Trend}

The second trend in the study of civilization in general and Islamic civilization, in particular employs philosophical and religious sources, methods, and approaches. Emphasizing concepts and ideas having their roots in philosophy and/or religious scriptures, studies in this trend underscore, for instance, the revolutionary nature of Islam as a religion, dated either from the last prophet Muhammad (pbuh) or from the creation of Adem. In this trend, Islam plays significant role and to extent that it assumes determinative role over all things necessary for civilization. Here, Islam as a religion and "complete" way of life serves as a necessary fertile ground for the initial genesis and development of Islamic civilization. 
Theories of Islamic civilization that fall under this trend would unequivocally underscore that the essence of Islamic civilization is Al-Tawhid (unity of God, monotheism) (AlFaruqi, 1992; Qutb, 2006). Methodologically, therefore, Islamic civilization is conceived in such a way that its emergence owes to Islam as a religion, and thus, to prophets, Qur'an, Sunnah, Al-Tawhid conception (for God and unity of Ummah), Shari'ah, and revelation are defined as the very fundamental bedrocks of Islamic civilization.

The most dominant feature of this trend is religious determinism although it, to some extent, embraces philosophical, and historical4. This is a recurrent theme across many Muslim thinkers who wrote about Islamic civilization. The works of Seyid Qutb (see, for instance, his "Ma'lim fi Trariq" (2006) and "Al-Islam wa Mushkilat al-Hadarah", (1962); Ismail Raji Al-Faruqi (See his "Tawhid and Its Implications for Thought and Life" (1992) and "The Cultural Atlas of Islam" (1986); and Sezai Karakoc (see, for instance, his "Dusunceler I" (2015), "Dirilisin Cercevesinde" (2014), and "Gunluk Yazilari II: Sutun" (1989).

\subsection{The Multiplexity Trend}

The last trend generally encompasses studies encompassing philosophical, historical, and religious orientations and factors. These studies adopted the interplay of religious views, empirical evidences, and philosophical ideas in their conceptions of civilization. Accordingly, different real life-empirical realities, political movements, institutions, and developments are posited alongside with religious and philosophical ideals. Unlike empiricism and religious determinism, theories that fall under this trend tend to embrace methodological plurality and open to possibilities that may have bearings on civilization. This trend in civilization studies, among other things, challenges reductionism both on methodological as well as epistemological grounds. Compared to the other two, it gives due attention to multiple factors, such as economic, political, cultural, religious, historical, philosophical, and physical factors, and the interlocking intricacies among them to account for the phenomenon of civilization. It can, thus, present an alternative and eclectic approach to civilization studies, and in that, it transcends the impasse posed by other determinisms and reductionisms, historical, religious, or biological.

Here, civilization is conceived as the product of historical experiences, natural conditions, religious phenomenon, and more importantly, as lived human experience. In dealing with Islamic civilization, therefore, this trend assumes both complexity and

\footnotetext{
${ }^{4}$ This, again, is drawn from my ongoing doctoral research, Alliance of Civilizations Institute, Ibn Haldun University, Istanbul, Turkey.
} 
multiplicity. Put simply, the idea here is that civilization cannot be simply reduced to historical, religious, sociological or philosophical factor; rather, it is the outcome of an interlocking bond and synthesis of these and other factors. Apart from the multiplicity of methods employed, it assumes complexity as it draws from the lived experiences and the higher level of abstractions. In what follows, I argue that, among other thinkers, the works of Ibn Khaldun (and his "Muqaddimah") and Said Halim Pasha (and his "Buhranlarimiz") best reflect these characteristics.

\subsubsection{Ibn Khaldun: From Reductionism to Multiplexity}

The present study, unlike the reductionist tendency to down play Ibn Khaldun's conception of civilization to a merely bio-psychological phenomenon called assabiyah, provides a relatively new insight. Of which, I argue that Ibn Khaldun's idea of civilization or Umran cannot be simply unlocked by stringing together bits of evidences scattered around in his Muqaddimah and surgically removing them from their contexts. Unfortunately, some studies of Ibn Khaldun's thought appear to yield an ardent "realistempiricist" while some others portrayed him as an honest follower of Aristotelian philosophy. Still others found at the core of Ibn Khaldun's thought of civilization what he termed as "assabiyah"- determinism, a sort of bio-psycho-social solidarity dictating the nature and form of Umran or civilization. For instance, some dubbed Ibn Khaldun as "secularist historian" (Turner, 1971: 43); "naturalist, empiricist" (Goodman in Kalpakian, 2008:367); "positivist" (Turner, 1971: p.45); "functionalist" (Gellner in Arnason and Stauth, 2004: p.29); "Cyclic theory of history"(Ibid, 45); and still others claimed he was the "founder of conflict sociology"(Ibid, 46).

No doubt that these appellations relegated Ibn Khaldun's thought in general and civilization, in particular, to nature deterministic and empiricist theoretical formulations. This general academic tendency, among other things, clouds and downplays the role of religion in Ibn Khaldun's venture into the social sciences. However, a well-known student of Ibn Khaldun, Muhsin Mehdi rejected the idea that Ibn Khaldun was an empiricist, historicist, determinist, positivist, or a pragmatist (See, for instance, Mahdi, 2015).

Contrary to these reductionist renderings of Ibn Khaldun's thought, I argue that a systematic reading of Ibn Khaldun's Muqaddimah reveals a greater degree of complexity and multiplicity. To this end, I argue for a more context oriented, eclectic, and multilayered reading of Ibn Khaldun's Muqaddimah. This engagement, cognizant of the possibility of two dimensions in Ibn Khaldun's imagination of umran or civilization, presents a view that complimentarily draws from empirical realities and Devin providence aspects. In other words, the attempt to reduce Ibn Khaldun's thought to 
either of the extremes mentioned could prove misleading and inadequate. Accordingly, although a sort of nature deterministic approach to Ibn Khaldun's thought of civilization might be attempted, an equally Devine providence perspective is also another possibility 5 . This becomes more obvious when we realize Ibn Khaldun's allegiance to "Asha'rism", which is known in Islamic thought for a greater degree of God's providence in relation to human action.

In this connection, one would argue that Ibn Khaldun explicitly underscored that human nature and action, and more generally, human civilization as God driven state of affair, a kind of providence that God has bestowed up on his creations. As a result, human survival and preservation of life ends up the necessary task of God. However, a different approach or reading of Muqaddimah can potentially, at the same time, posit another side or face to human action and civilization. This later view of civilization can be considered a nature deterministic perspective. In this perspective, like many other social and natural scientists, Ibn Khaldun holds that human nature and action, and thus, civilization is nature deterministic process and geared towards survival and preservation of human species.

Notwithstanding these extreme renderings of Ibn Khaldun's thought, it is in light of the creative synthesis of these two perspectives where, I argue, Ibn Khaldun's contribution to the study of Umran or civilization lie. If a holistic reading of Ibn Khaldun's thought is attempted, then the emerging synthetic perspective would prove much safer, contextually sensitive, and thus, more meaningful. This third perspective, which I called above multiplexity, in Ibn Khaldun's thought signifies religious based ontological and epistemological orientations; historic-empirical realities and observations, and philosophical positions.

In addition, the synthesis of his religious predisposition needs to be contextually evaluated along with his own personal experiences in politics, religious activities and own philosophical and sociological projections ${ }^{6}$. In what follows, therefore, I flesh out two important aspect of Ibn Khaldun's thought about civilization ("Umran"). The first aspect examines what can be called nature-deterministic dimensions of civilization. The second aspect explores the role of divine providence and the concept of vicegerency

\footnotetext{
5 See, for instance, Busch, B.C. (1968). "Divine Intervention in the "Muqaddimah" of Ibn Khaldūn. History of Religions, Vol. 7, No. 4, p. 317-329.

6 For Arnason and Stauth (2004, p.33), the religious dimension is in as much important as other aspects of Khaldunian understanding of civilizational analysis.
} 
("Khilafa") of man on earth. Finally, I conclude that understanding Ibn Khaldun's view of civilization demands both multiplicity and complexity in method and content.

\section{Umran and the Natural World}

Ibn Khaldun saw human settlement on earth as something closely related to the availability of oceans, rivers, and overall climatic conditions. In this way, he posited human civilization "umran" along with natural conditions. In this context, he noted "the part of the earth that is free from water and suitable for human civilization ("Iilumran") has more waste ("qafaar") and empty ("khil'a") areas than cultivated-habitable ("umranahu") areas. The empty area in the south is larger ("akthar") than that in the north" (Ibn Khaldun, 2013:100). Even though the part of the earth that is free from water is about one-half or less, the cultivated part covers only about one-fourth of it. Based on this observation, Ibn Khaldun, following Ptolemy and Roger, divided this part of the earth into seven zones ("Aqalim"). It should be noted that this classification assumes direct connection between Umran and geographical conditions. Specifically, his classification was based on the assumption that climatic conditions affect the ecosystem, human activities-social, economic and cultural, and thus, the level of Umran. Basically, Ibn Khaldun believed that in the cultivated part ("juz'a al-ma'mur") of the earth, there are many rivers. The largest among them are four in number: Nile, Euphrates, Tigris, and River of Balkh, which is called Oxus (“Jayhun”) (Ibn Khaldun, 2013:103).

Employing hi own observation ("bil mushahadah") and verifiable reports ("wal akhbar almutawatir"), of the seven zones, Ibn Khaldun underscored that the first and second zones are less cultivated, and thus, have less (in cultivation, and thus, much less suitable for life) civilization ("Aqal umranen mima b'adiha"). These zones are less cultivated and habitable and its manifestations, among others, included that they have less nations ("umam"), population ("wa anasyhim"), cities ("amssaruhu"), and towns ("madinahu"). When it comes to the third, fourth and what comes after these, the condition of civilization is reversed. Unlike the first and second zones, the nations and populations are tremendous, and cities and towns are exceedingly numerous ("tajawaz al-had "adadin") in zones after the first two. In these parts of the world, he believed that civilization remains to be much higher ("mundaraj") while the south, the first and second zones, is completely empty ("Khil'a kulluhu") (Ibn Khaldun, 2013:105)7. This difference in the level of civilization is attributed to natural conditions. In other words, while the

\footnotetext{
7 In other place, he changes the vocabulary from "wal junub khil'a kulu" to "kan al-umaran fi iqlim al- 'ula wa thaniya qalilan"(Ibn Khladun, 2013: p.105).
} 
south tends toward hot, and thus, makes cultivation difficult, the north tends toward cold with the reverse effect.

Ibn Khaldun found that countries located more to south, of Africa are less moderate, and thus, unsuitable for civilization. He included such countries as Ghana, Slavs, South Sudan, part of Mali and others in the first and second zones (that is, countries in the North and South end of the earth). When it comes to certain parts of the second, the third, fourth and fifth zones, the condition was relatively moderate. He included such countries as North of Sudan, Christian Turks, Abyssinia, Persians, Arabs, France, Greeks, and others. However, the ideal climatic condition suitable for human cultivation and thus civilization was located in countries like Syria and Iraq.

While analyzing the Umran level of the seven habitable, albeit varying in degrees, part of the earth, Ibn Khaldun gave particular emphasis on certain attributes which, in turn, are very crucial to understand what he meant by Umran itself. Some of the factors he used as rubric included what he called "al Ahwal" (conditions). This condition (both material and non-material aspects) encompasses architecture (building styles, homes), subsistence (food), clothing style, economic transactions, character, prophecy and collective life. These are, among others, the most important themes that defined lbn Khaldun's discussion of Umran, both in specific and general contexts. I argue, therefore, that it is through these yardsticks and measures that he sought to differentiate between places and societies of higher (perhaps complex) level of Umran from those with less or lower level.

To begin with, in the first and second zones, Ibn Khaldun found, there were sufficient reasons to consider them assuming lower level of Umran than those of the third, fourth, fifth, and six zones. He argued that people in these climatic conditions tend to have buildings built on clay ("bi-tin") and reeds ("wa al-qasab"); their subsistence on durra ("al-zirah") and herbs ("wa al-'ashb"); their economic exchanges ("wa mu'ameletihim bi ghayr al-hajarayin al-sharifayin') on copper, Iron or skins not on the two noble metals; their characters are close to dumb animals ("wa akhlaqihim qaribatun min akhlaqi alhaywanat al-'ajm") and act savagely ("wa'anahum mutawhishun") and eat each other (y'akulu ba'duhum b'adua); and finally, in their religious conditions, they are ignorant of prophecy ("fela ya'rifuna nubuwa wala yadinun bisharia' $h$ ")(Ibn Khladun, 2013:143). Due to these conditions, Ibn Khaldun concluded, zone one and two are remote from the state of being human and close to those of wild animals ("wa jami'a ahwalihim ba'edatun min ahwal al-unsaya qaribatun min ahwal al baha'em") (bid,143). 
Contrary to the first and second zones, the overall conditions of Umran, both in terms of habitation and cultivation, assume moderation in places like Maghrib, Syria, Hijaz, Yemen, Iraq, India, China, and Andalusia (lying between the second and the seven zones). Of these, both Iraq and Syria represent the most temperate and ideal of all places, and thus, higher level of Umran. Among other things, all of these places share important characteristics, such as houses built on stones and embellished by craftsmanship ("ye tahizun al-buyut al-minjidah bilhajarah"); undertake their businesses through the two precious metals-gold and silver; and they avoid intemperance in all their conditions ("wa yeb'adun an al-inhiraf fi amah ahwalihim") (Ibid, p.142). In other words, these zones were endowed with all the necessary conditions for sustaining civilization ("wa kafatu al-ahwal al-tabi'ah lil'etimar"). In this regard, they could be distinguished by ways of making a living ("m'ash"), dwellings, crafts, sciences, political leadership ("rayyasat"), and royal authority. They have experiences of prophecy, religious groups, dynasties, religious laws, sciences, countries, cities, buildings (“mabani”), horticulture (“furassah"), and splendid crafts ("sin'a al-fa'eqah') (Ibid, p.145).

\section{Umran between Bedouin and Settled Societies}

Ibn Khaldun's view of human condition in general and among Bedouin societies, in particular, is based on empirical data, own observations, and reports (and thus rarely invokes religion). Here, it can be easily seen that he relied more on what has come to be called the "Great Chain of Beings" and nature deterministic perspective ${ }^{8}$. It is through this frame of reference that he conceived the nature and form of life (and thus Umran) among the Bedouins. In this regard, Ibn Khaldun argued that human beings generally occupied a place above animals, but below angles. He argued, by adopting Aristotelian "chain of beings", that, "the animal world then widens, its species become numerous, and in a gradual process of creation, it finally leads to man, who is able to think and to reflect $^{9}$ (Ibid, p.172).

In this world of humans, life is precarious, dangerous, and unpredictable. In order to succeed, and thus, preserve life in this Khaldunian 'state of nature', it is necessity to have certain unique survival basic instincts, skills, and generally, mechanism of coping and surviving. In this 'state of nature' human beings need, among other things, food and security to survive. However, the power of the individual human being is not

\footnotetext{
8 Traced back to Aristotelian philosophy of "scala naturae" also sometimes known as ("ladder of nature").For further discussion see Arthur, O. (2001)'s The Great Chain of Being.

9 The Arabic version reads: "wat-tasa alem al-haywanat wa ta'dadat anwa'aha wantaha fi tadaruj al-takwin il al-insan sahib al fikr wa ru'eya" (Ibn Khaldun, 2013; p.172).
} 
sufficient for him to obtain (the food) he needs, and does not provide him with as much food as he requires surviving ("an qudrat al-wahid min al-bashar qasirah an tahsil hajatahu min zalik al-ghiza") (Ibid, p.97). Similarly, each individual needs the help of his fellow beings for his defense (" $f i$ difa'a an-nafsihi il al-isti'anah bi'abna'a jinsihi'). However, the power of one individual human being cannot withstand the power of any one dumb animal, and therefore, unable to defend himself against them by himself. Consequently, these two conditions constitute the 'prime causes' of Khaldunian theory of civilization. The first is the need for economic institution and the second is for political institution. These social institutions are still impossible without the second 'necessary cause', namely, cooperation ("al-ta'awun") and social organization.

At the heart of this is group feeling ("assabiyah"). This group feeling is the basis of mutual cooperation among fellow human beings for every mass undertaking, economic or political, by necessity requires group feeling ('in kula amrin tahmil aleyhi al-kaafa'h fala bud laha min al-assabiyah") (p.279). Without, therefore, developing cooperation through group feeling, human beings' survival, feeding itself and security from any danger, could have been impossible. Likewise, when this "mutual co-operation exists, man obtains food for his nourishment and weapons for his defense" ("fala bud fi zalik kulluhu min at'awun . . wa maalam yakun haza al-ta'wun fala yahsil lahu quwa'h wala ghiza'a") (p.98). Apart from cooperation, human beings cannot exists in a state of anarchy ("muqatalah . . . il-dim'a wa 'izhab al-nufus") and without a ruler ("al-malik alqahir") who keeps them apart, restrain them and exercises authority (p.322).

Again, all these are only possible because human beings have unique qualities ("ikhtassa biha") that distinguished them from other creatures. These qualities included the sciences and crafts resulted from the ability to think (al'ulum wa sina'a alati hiye natijat al-fikr) which exalts ("tamayaza bihi . . . al al-makhluqat") him over all creatures; the ability to exercise restraining influence (al-hukm al-wazi'e) and strong authority ("sultan al-qahir") of which man, compared to other creatures, cannot exist without ("layumkin wujudahu duna zalik'); man's efforts to make a living ("ass'ay fil ma'ash"); and at the end, civilization ("al umran")10 (Ibn Khaldun, 2013: 95-96). In short, the sociopolitical and economic needs of human beings are met by means of adopting necessary survival basic instincts and skills, such as group feeling, cooperation, authority, and thus, civilization. In this Khaldunian 'state of nature', human beings are conceived to be in constant state of perfection, of which nature contributes both the physical and

\footnotetext{
10 Huntington, S.P. (1996, p.43) considers civilization as " the broadest cultural entity ... which distinguishes humans from other species..."
} 
sociocultural ingredients. Human body color (p.142), body proportion (p.147), human personality, character, and courage (p.223-248), and religious conditions (p.150), and others are attributed to the physical environment.

On the sociocultural domain, human beings are viewed as the product, or as Ibn Khaldun himself calls it, the "child" of his sociocultural environment ("in al-insan ibnu 'awa'idahu wama'lufihi") (p.233). In fact, he went so far as to claim that man is not the product of his natural disposition and temperament. The conditions, to which he has become accustomed, until they have become for him a quality of character and matters of habit and custom, have replaced his natural disposition ("la ibnu tabi'atehu wamizajihi . . .hata saara huluqan wamalakatan wa'adatan tunzalu manzilat al-tabi'at wal-jibilah") (Ibid). The customs, traditions, and various behaviors such as 'habit of goodness and evil' (p.227), 'sociability', 'savagenes', 'bravery' and 'courageousness' (p.232), 'fear, docility and fortitude' (p.233), friendliness, 'levity', 'excitability', and 'great emotionalism', and related other conditions of human beings are attributed to the socio-cultural environment. In this state of nature, being rational, human beings do not act individually for it has inherent risks and unsustainable, but collectively for its abundance, sustainability, and security. In what follows, I move onto the religious dimension of Ibn Khaldun's appraisal of Umran.

\section{Umran, God, and Man's Vicegerency}

Anyone reading Ibn Khaldun cannot help but notice the religious context, coloring, or aspects in any issue he discusses in his Muqaddimah. Umran, being the central organizing principle and science of Ibn Khaldun's Muqaddimah, cannot be disentangled from this embedding context. Ibn Khaldun's idea of Umran embodies such factors as nature ("empirical")-biological, environmental; socio-cultural, and historical factors-and religious contexts-as in God's providence and the vicegerency of man.

The religious corner of Ibn Khaldun's Umran is in as much important as the naturedeterministic aspect. Here, it could be argued that Ibn Khaldun's thought assumes God's plan for Human beings on earth. In this plan of God, human beings are designated with His vicegerency ("Istikhlaf") on earth (p.98). In order for this to happen, God provided everything for human beings, without which human being's existence on earth would be impossible. As a result, God 'gave everything its natural characteristics, and then guided it' (Surah al-Taha, Ayah-50) (p.99). Human beings being part of the "every creation" are endowed with the necessary survival mechanisms and "guided" them in the right path that would enable them to preserve their species. In order to meet the needs and wants 
of human beings, and thus, its preservation, God gave man of all that is needed. These divine providences also included natural and socio-cultural domains.

Addressing the natural environment, Ibn Khaldun argues that for the success of God's plan for the vicegerency of man and for civilization and for the preservation of life resulted in making part of the earth free of water. Not only did God give the natural conditions for the survival, preservation and continuation of human species, but also the socio-cultural conditions. One of which is a necessary ingredient of any social organization that marks Khaldunian thought of human nature, culture, and civilization is assabiyah, or loosely translated as "group feeling". This bio-psycho-social concept is a blood based relation and feeling towards a group or members of a group, is still a divine providence from God. For this, he says that compassion and affection for one's blood relations and relatives exist in human nature as something God put into the hearts of men ("wa ma ja'alallahu fi qulubi e'ibadihi min al-ashafaqah wa na'arah ala zuwi arhamahum waqarabaa'ihim mawjudaha fi tab'a al- basher'). It makes for mutual support and aid ("al-ta'dhud wa al-tanassur') (p.236).Group feeling and cooperation among human beings are from God; otherwise, he invokes God's promise that 'If you had spent all that is in the earth, you could not have brought their hearts together; but Allah brought them together' (Surah al-Anfal; Ayah-63) ${ }^{11}$ (p.171).

Apart from group feeling and cooperation, God also ensured the security and safety of human beings on earth through facilitating authority. Ibn Khaldun, in light of Qur'anic verse that God saying "We led him along the two paths", points out that these 'paths' are those which "God put into man", namely, evilness and goodness ("in Allaha subhanahu rakkaba fi tab'a al-basher al-khayr wa al-sher') (p. 235). These qualities represented, in human beings, wickedness ("fujur") and fear ("taqwa") of God. Since the evil quality of human beings included injustice ("zulm") and aggression ("'udwan"), God enabled human beings with authority; otherwise, 'If God did not keep human beings apart, the earth would perish' (Surah al-Baqarah, Ayah-251) (p.254).

In this second aspect of Ibn Khaldun's conception of Umran, human beings generally acquire or achieve the plan of God. Human beings are represented in a way that resembles players in the field created by God. The players and the field is of God, but given the fact that human beings are shown both the right and wrong direction in their attempt to play the game, both in their physiological and psychosocial make up, they

\footnotetext{
11 The Arabic book I'm using for this research mistakenly attributed this verse to "Surah al-Hijr" (see, Ibn Khladun, "Muqaddimat Ibn Khaldun"Dar Al-Kotob Al-Ilmiyah, Lebanon, 2013; p.171).
} 
achieve 'the plan' of God. Owing to his weaknesses and inabilities inherent in his creation, human beings need God for the preservation of own species, and thus, the fulfillment of God's original plan, man's vicegerency on earth. Accordingly, human beings survive meeting their needs, primarily, economic and political needs. These needs, being the inherent weaknesses of man, God provides, besides creating them, all the necessary ingredients-the natural and social environment. Group feeling, cooperation, authority and civilization are, therefore, God's ways of dealing with human beings on Earth 12 .

In conclusion, it could be clearly seen that Ibn Khaldun's approach to umran or civilization synthesizes different conditions and factors, on the one hand, and methods, on the other. In addition to the above two key aspects of Ibn Khaldun's Umran, there are historical, philosophical and empirical dimensions to it. It is clear that he adopted examinations-historical ("tahqiq"), causations ("'illa"), personal experiences ("tajrubah"), observations ("mushahadah"), and verified and continues reports ("al akhbar al mutawatir"), logic and others as methods. These methods helped him to triangulate and verify various assumptions, philosophies, myths, prior theories and others. This not only helped him reduce the chance of making erroneous mistakes, but also strengthened the power of his conclusions and deductions. In terms of content and focus, Ibn Khaldun's study of Umran encompasses nature-biological and environmental aspects, historical accounts, religious notions and experiences, economics and trade, sciences, agriculture, pastorialism, rural and urban sociology, politics, human psychology, and others. This, consequently, makes Ibn Khaldun's engagement of Umran or civilization multiplex, assuming multiplicity and complexity.

\subsubsection{Said Halim Pasha}

Another thinker that arguably falls under the multiplex trend in the study of civilization in general and Islamic civilization, in particular is the Wazir of the late Ottoman Empire, Said Halim Pasha. Interestingly, like Ibn Khaldun, Said Halim Pasha was not an armchair speculator as is usually the case for many western theoreticians of civilization ${ }^{13}$. He was an active participant in the political as well intellectual scenes of the late ottoman era. Like Ibn Khaldun, the multiplexity reflected in his idea of civilization, particularly Islamic

\footnotetext{
12 In fact, this is what Ibn Khaldun considers al-umran. He says "al-umran. . . wa bayaanuhu inallaha subhanahu khalaq al-insan warakkabahu ala surat la yassih hayatiha wabaq'auha ila bilghiza'a wahadahu tamaassuh bifitratihi' (Ibn Khaldun, 2013; p.97).

13 It is very important to underline that Ibn Khaldun's and Said Halim Pasha's work are the necessary reflection of their lived experiences, not just students of "classical books", and thus, arm chair speculators. Also, the multiplexity of their thought partly drives from this experience.
} 
civilization and its ottoman off shot, draws significantly from his practical-empirical, political, philosophical and ideological experiences and thoughts. Being a dedicated Islamist, Said Halim Pasha's (hereafter as "Pasha") general thought resonates with the overall ottoman Islamic and political thought, which, in turn, cannot be detached from the influence of Ibn Khaldun (see, for instance, Ardic (2012)).

As I will discuss shortly, Pasha's thought generally assumes multiplicity in the dimensions explored and the complexity of his account. In what follows, principally drawing from his book titled "Buhranlarimiz"(“Our Crises")which encompassed seven of his earlier writings, I attempt to flesh out Pasha's thought along three major issues: the first part deals with his view of Islam and Islamic civilization (and thus the ottoman empire as an important empirical reflection); the second part comparatively appraises how he views Islamic civilization in contradistinction to western civilization; and finally, the last part ends with highlighting what he considered to be the locus of crises in Islamic civilization.

I argue that these dimensions can serve us important anchors to decipher Pasha's view of civilization in two important ways. On the one hand, the first two dimensions can collectively provide normative as well as philosophical vantage points to Pasha's understanding of civilization. The third dimension, which is, in fact, the very purpose of Pasha's writings in "Buhranlarimiz" can provide us with an understanding of empirical, historical, and sociological constituents and being of Islamic civilization, on the other. In other words, by dealing with aspects of the crisis of Islamic civilization, Pasha is to actually analyze the vital or secondary aspects of Islamic civilization where this crisis is conditioned. Put differently, by discussing the crisis and revival of Islamic civilization, Pasha is dealing with the very essence and being of Islamic civilization. As I will show shortly, this is the very reason why Pasha's understanding of Islamic civilization merits to be examined under multiplex trend, subsuming and reflecting multiplicity and complexity, in the study of Islamic civilization.

\subsubsection{Islam and Islamic Civilization}

When Pasha wrote about civilization what he had in mind was Islamic civilization in general and Ottoman Empire, in particular. Although he viewed Islamic civilization in close proximity to Islam, he emphasized the challenges and prospects of Ottoman Empire. In either case, the frame of reference remained Islam. In fact, he made it clear from the outset that the crisis the Ottoman Empire experiencing in its latest stage was closely aligned with its general tendency to move away from Islam, both in theory and practice. It is for this very reason that a close assessment of Halim Pasha's view of Islam and its relation to civilization and the Ottoman Empire is warranted. A critical reading of Pasha's 
"Buhranlarimiz" ("Our Crises") would reveal that there are some important ways through which he understood and deployed Islam. In what follows I deal with three of them, Islam and its ability to devolve a political society and civilization of its own; Islam and Shari'ah; and finally, Islam and "Akhlaq" (character, morality, etc) ${ }^{14}$.

Pasha was of the opinion that religion determines everything, every aspect of life. Religion encompasses both "material and nonmaterial domains of human individual and collective existence"15 (Pasha, 2015:148). Islam, unlike other religions, cannot be simply reduced to idealism or positivism as some would have us believe, he noted. In fact, Islam not only "encompassed these, but also entails other important elements beyond" (Ibid, p.186). As a religion, Islam is a "lived truth and ultimate reality" (p.170). Simply put these and related other factors made Islam the "perfect religion (of humanity) that encapsulated all aspect of human life on earth" (p.185).

However, Islam, for Pasha, did not confine itself to spirituality. It went far beyond it. It made civilization possible. Apart from these internal peculiar aspects of Islam, it has also produced political societies that in turn set in motion Islamic civilization, to which Ottoman Empire was the last political heir up until the first quarter of the twentieth century. Here Islam is appraised as the one which gave rise to many empires ("her biri ayri imparatorluk') and political societies in the world (Ibid, p.150). Islam made this possible through its own principles underlying social and political systems. It was Islam's basic principles of unity and brotherhood, unlike nationalism in Christian Europe, which facilitated political unity of Islamic civilization under Ottomans (p.67).

Other peculiar principles underlying ("Is/am inancindan dogan") Islamic civilization in general and during the Ottoman Empire, in particular, included freedom ("hurriyet"), equality ("esitlik"), justice ("adalet"), humanity ("insanlik"), and morality, character, or manner ("ahlak") (p.60-69). Accordingly, the strength of Islamic civilization was the product of a "comprehensive understanding of Islam (and its principles) and systematic application of it taking into account changing circumstances" (p.64-67). Being the best of examples, it was Islam that gave rise to Islamic civilization from a dessert; established borderless ("hudutsuz") empires; and ultimately solved the problem of racism ("irk tedkiklerinde") through a comprehensive sociopolitical system (p.108). However, Islam was not only responsible for the advent of Islamic civilization, but also "played significant roles in the later emergence of western civilization"(p.119).

\footnotetext{
14 "Akhlaq" is hereafter defined as morality.

15 Author's translation and the same apply to forthcoming citations.
} 
The second important way through which he approached Islam in his discussion of Islamic civilization with a particular emphasis on the Ottoman Empire was centered on the idea and practice of Shari'ah. In fact, it can be seen that Pasha saw Shari'ah as the very quintessential being of Islam lying somewhere between the ideal teachings of Islam and its worldly actual realization in terms of civilization, political system, social institutions, and various empires in Islamic history. The importance of Shari'ah for Pasha lies in its ability to devolve society, political society, and more generally, civilization.

He argued that Islamic societies are closely tied together with the idea of Shari'ah ("Isalm cemiyeti seriat'in hakimiyetine tabi ve baglidir"). This means that these societies lived and were the expressions of the moral as well as social norms of Shari'ah ("ahlaki ve sosyal kanunlari'), and in so doing, it ascertains the fact that "there are certain fixed normative prescriptions of Shari'ah that order social and political conditions"(p.251). Founded upon the principles of equality, freedom, justice, brotherhood ("Islam kardesligi"), family ("Islam ailesi"), and ethics or morality, Islamic Shari'ah brought about a new society and civilization. It brought with it, "from nothing, a civilization characterized by science, wisdom, justice, enlightenment, happiness, and its social, spiritual and material conditions were never seen in the world" (p.231).

The third important frame of reference Pasha recurrently deployed throughout "Buhranlarimiz" (our crisis) is closely tied to the Islamic concept of "Akhlaq". For Pasha, the importance of morality is very foundational that he viewed it as the key to explain the crisis as well as revival potentialities of Islamic civilization under the Ottoman Empire ${ }^{16}$. This is exactly what he meant when he argued that "morality should come before anything in an effort to rejuvenate and strengthen the Ottoman Empire" (p.137). It is not only the means for reviving Islamic civilization, but also one of the very purposes of Islamic society and civilization. In this connection, he pointed out that "the ideal society aims for cultivating and producing individuals of high moral character" (Ibid).

He went one step ahead and argued that it is morality that defines what it means to be an Islamic society, for it is this morality that produces that ideal Islamic society. Accordingly, the relationship between Islamic morality and society assumes two-way interactive dialogues although the influence of the former is more of foundational and constitutive than the latter, and thus, assumes the power to alter the nature and form of the latter. If

\footnotetext{
16 While discussing the crisis of Islamic civilization under the Ottoman Empire, he raised this very issue and argued that "the danger that caused crisis among citizens was due to the lack of sense of morality" (Pasha, 2015:124).
} 
we, for instance, take Islamic morality, it determines the nature (foundation) of "justice, equality, freedom, and solidarity (and cooperation) between members in a given society" (p.190).

On the other hand, on the corner of Islamic society, the ideal society and individual members reach greater glory if and only if they properly understand and implement the basic teachings of Islam (including the percepts of morality). If this goes well, then the purpose of establishing Islamic political society becomes fulfilled. In other words, Islamic political society is impossible "without properly implementing Islamic morality and social system" (Ibid, p.193). Islamic morality, however, cannot be detached (and thus, does not have a life of its own) from Islamic religious belief, for it is Islamic belief that gave birth to Islamic morality ("Islamin inancindan dogan cemiyet ahlaki")(p.190). Put differently, Pasha believed that societies' level of morality and spirituality go hand in hand with levels of freedom, equality, and welfare (p.191). Finally, like Sezai Karakoc and Ismail Raji Al-Faruqi, Pasha underscored that the basis of Islamic morality is Islamic monotheism (otherwise known as al-Tawhid) (“Isalm ahlakin kaynagi, hak olan tek Allah'a imandir") (Ibid, p.189).

\section{Pasha's Islamic Civilization: A Comparative Perspective}

In attempt to show the relative merits of Islamic civilization, Pasha consistently employed comparative approach throughout "Buhranlarimiz". He specifically compared Islamic civilization, often exchanging it for the East, with Western civilization. I argue that Pasha's comparison primarily revolved around three major themes. The first dimension explored issues closely related to the origin and nature of civilization. The second aspect analyzed social systems (particularly social structure and politics) in both civilizations. The third theme encompassed issue of change and progress in these two civilizations. Taking into account these three dimensions, he concluded that there were very fundamental differences between these civilizations. A brief comparative appraisal of these elements is in order.

When the origin and nature of civilizations is examined, he saw certain attributes that made western civilization distinct compared with Islamic civilization. He, for instances, argued that western civilization, with the advent of natural and positive sciences, detached itself from Christianity, and in the process, devolved philosophical speculations and materialism (p.147). It was then clear that western civilization, operating this way, had already invented a new religion at the expense of Christianity, this time not under prophets or priests, but under the leadership of scientists and philosophers ("yeni 'murisdler' toplulugunun lehine olmustur") (p.147). The outcome of this was a western society that has cherished comfort and safety in the newly instituted secular order (p.176). The same 
thing, however, cannot be said for Islamic society and civilization. In fact, to the contrary, Islamic societies acquired their peace and comfort from their Islamic faith and their Islamic morality and thought (Ibid). Unlike western civilization, Islamic civilization took its inspiration from Islam in general and Shari'ah, prophets, Islamic morality, freedom, justice, and solidarity, in particular (Ibid).

The second important comparative theme in "Buhranlarimiz" of Pasha is the difference in the very idea of progress and change in civilization. He pointed out that since its initial genesis western civilization has been going through changes without any identifiable purpose. The change was very transformative that every aspect of life would be subjected to change ("daimi olarak degistirmek ihtiyacini duymus ve duymaktadir") (p.242). Making, then, itself busy with temporarily meeting needs that arise in its march for growth, it remained purposeless and without any lasting values ("Belirli ve degismez bir gay eve hadef sahip olmayan Bati ...") (Ibid). Being realist and positivist by its very nature, it was not directed by certain unchanging values; rather, in the process of meeting and changing its material, emotional and technological needs, its existential purposes would change at the same time (Ibid).

The same is true for its sociopolitical organization as well. It started with Church playing the role of spiritual leadership. This then, through time, led to kingship, which helped garnering significant wealth. As the new bourgeois class amassed huge wealth and prosperity, it paved the way for the advent of democratic system. Due to this unsettling urge for change and transformation, western civilization, according to Pasha, "remained dissatisfied and unhappy" (p.243). However, for Pasha, this does not apply to Islamic civilization. This is because the "foundations of Islamic institutions do not change; not because they cannot change, but because they are in perfect condition that they do not need changes" (p.177).

Finally, the last important comparative theme in "Buhranlarimiz" of Pasha is the difference in social system (social structure and politics, in particular) between Western and Islamic civilizations. While sociopolitical life among Muslims in Islamic civilization was the product of the Islamic system of morality-the root of which, again, is traced back to Islamic faith(p.185), the case in western civilization in something different. He argued that in history, western societies relied on "historical nobility" ("tarihi asalet") and the bourgeois ("burjuva") class to structure their socioeconomic and political activities. This class, according to Pasha, was unimportant ("ehemmiyetsiz") to Ottoman Empire. Although this class had very powerful power and role in western societies, it was never the case for Ottoman society. In fact, the most comparable position in Ottoman Empire was called 
"memurlar" (civil servants) and they were held in higher regard and respect (p.62). Interestingly, every scholar and intellectuals in the Ottoman Empire would wish to become one of these civil servants (despite its negative implications for intellectual independence, neutrality, etc).

\section{"Buhranlarimiz"}

Said Halim Pasha, being a statesman of the Ottoman Empire era, had both the opportunity and experience to easily recognize and spot change trajectories characterizing Islamic civilization. Being a statesman of the Ottoman Empire, he was well aware of the crises of Islamic civilization, especially in the late nineteenth and early twentieth centuries. The book "Buhranlarimiz" is the recollection of his practical experiences and insights into this very condition. It can be seen that he knew, much earlier than other thinkers and social scientists that Islamic civilization was going through periods of crisis and lagging behind world leadership (p.231). In spite of this crisis consciousness, there was not any satisfactory study into this phenomenon at the time. He believed that many of the causal explanations were not only inadequate, but also very far removed from Islamic civilization and its Ottoman context (p.150).

Under "Buhranlarimiz", Pasha explored various and multifaceted causal factors behind the crisis of Islamic civilization. The causes he identified included such factors as various steps and actions taken against Islam; backwardness in the natural sciences; problems caused by reformers, statesmen, and thinkers; pre-Islamic and western influences; materialism; and others. Analytically speaking, a close analysis of "Our Crisis" engages three interrelated ingredients. The first dimension, and vast in its coverage and penetrative in its depth, is crisis factors closely posited with intellectuals.

The second ingredient encompasses local rulers, religious scholars and other internal conditions. The last aspect of the crisis of Islamic civilization, which mostly dealt in conjunction with the first two dimensions, is the multifaceted influence of the West. Although much of Pasha's efforts were directed at understanding and explaining these causal factors, he did not ended the discussion at the level of description and explanation only. In fact, he went one step ahead and forwarded possible measures that he believed could facilitate the way for the rejuvenation of Islamic civilization in general and ottoman Empire, in particular. This later part is what he styled Islamization ("Islamlasmak"). 


\section{Conclusion}

While many theories of civilization in general and Islamic civilization in particular fall under the historic-empirical and religiophilosophical trends and approaches, there are few theories, of Islamic civilization, that typically show certain degree of multiplicity and complexity in method and approach. Many, if not all, theories in civilization studies are confined to either historic-empirical, with extreme forms as in historicism and positivism, or religiophilosophical theoretical and methodological formulations. However, the multiplex trend, which has been appraised to subsume multiplicity and complexity, both in theoretical abstraction and methodological plurality, has been commonly employed among Muslim thinkers theorizing about Islamic civilization.

Of these thinkers, the present study examined the works of Ibn Khaldun and Said Halim Pasha. Apart from methodological plurality and eclectic focus, their appraisal of civilization in general and Islamic civilization, in particular, drives largely from their own lived experiences in their respective periods. It can be safe to conclude that, unlike those armchair speculators (determinisms, reductionisms, and etc), these two thinkers attempted to construct a theory of civilization they believed was too complex to reduce to any single aspect of human life and this meant that they needed to provide a wider theoretical foundation both in method and content.

\section{References}

Al-Faruqi, I. R. (1992). Al Tawhid: Its Implications on Thought and Life. International Institute of Islamic Thought.

Al-Fārūqī, I. R., \& Al Faruqi, L. I. (1986). The cultural atlas of Islam. Free Press.

Ardlç, N. (2012). "Genealogy or Asabiyya? Ibn Khaldun between Arab Nationalism and the Ottoman Caliphate". Journal of Near Eastern Studies, 71(2), 315-324.

Arnason, J. P., \& Stauth, G. (2004). "Civilization and State Formation in the Islamic Context: ReReading Ibn Khaldūn". Thesis Eleven, 76(1), 29-48.

Busch, B. C. (1968). "Divine Intervention in the" Muqaddimah" of Ibn Khaldūn". History of Religions, 7(4), 317-329.

Hodgson, M. G. (1960). "A Comparison of Islam and Christianity as Framework for Religious Life". Diogenes 8 (32):49-74.

Hodgson, M. G. (1974). The Venture of Islam, Volume 1-III. University of Chicago Press.

Hodgson, M. G., \& Burke, E. (1993). Rethinking world history: essays on Europe, Islam and world history. Cambridge University Press.

Huntington, S. P. (1997). The clash of civilizations and the remaking of world order. Penguin Books India.

Ibn Khaldun, A. (2013). Muqaddimah Ibn Khaldun. Lebanon: Dar Al-Kotob Al-Ilmiyah,. 
Kalpakian, J. (2008). "Ibn Khaldun's influence on current international relations theory". The Journal of North African Studies, 13(3), 363-376.

Karakoç, S. (1986). Gunluk Yazilari IV: Gun Saati. Diriliş Yayınları.

Karakoç, S. (1989). Gunluk Yazilari II: Sutun. Diriliş Yayınları.

Karakoç, S. (2014). Dirilisin Cercevesinde. Diriliş Yayınları.

Karakoç, S. (2015). Dusunceler I. Diriliş Yayınları.

Khaldun, F. I., \& Rosenthal, N. J. (1967). The Muqaddimah: an Introduction to History, Translated From the Arabic by Franz Rosenthal, Abridged and Edited by NJ Dawood.

Mahdi, M. (2015). Ibn Khaldun's Philosophy of History: A study in the Philosophic foundation of the science of culture. Routledge.

Mazlish, B. (2004). Civilization and its Contents. Stanford University Press.

Paşa, M. S. H., \& Düzdağ, M. E. (1991). Buhranlarımız ve son eserleri. İz yayıncılık.

Qutb, S. (1962). Al-Islam wa Mushkilat al-Hadarah. Cairo: Dar Ihya' al-Kutub al-'Arabiya

Qutb, S. (1964). Ma'alim fi-l-Tariq (Milestones). Cairo: Dar al-Shuruq.

Şentürk, R. (2010). Açık medeniyet: Çok medeniyetli dünya ve topluma doğru. Timaş Yayınları.

Toynbee, A. J. (1952). Study of history. Vol I-12. Oxford: Oxford University Press.

Toynbee, A. J., \& Caplan, J. (1972). A Study of History-The New One-volume Edition, Illustrated. Oxford University Press.

Turner, B. S. (1971). Sociological founders and precursors: The theories of religion of Emile Durkheim, Fustel De Coulanges and IBN Khaldûn. Religion, 1(1), 32-48. 